\title{
Micellar Enhanced Ultrafiltration for the Removal of Polycyclic Aromatic Hydrocarbons (PAHs) Mixtures in Underground Contaminated Water in Oman
}

\section{Mohamed Aoudia*, Amal Al-Sabahi**, Salma Al-Kindy, Mahfoodh Al-Sheily and Fouzul Marikar}

Department of Chemistry, College of Science, Sultan Qaboos University, P.O. Box 36, Postal code 123, Muscat, Sultanate of Oman, ${ }^{\star}$ Email: aoudia@squ.edu.om. ${ }^{\star *}$ Ministry of Education, Muscat, Sultanate of Oman.

استخدام طريقة الترشيح الاقيق المعزز بالمسيل لمعالجة الهيروكربونات الأروماتية متعدة الحلقات في المياه الجوفية الملوثة في عمان

$$
\text { محمد أوديع، أمل الصبحي، سلمى الكندي، محفوظ الثعيلي وفازول ماريكار }
$$

ملخص: في محاولة لتحليل المياه الجوفية الملوثة بكميات من الهيدروكربونات الأروماتية المتعددة الحلقات في منطقة

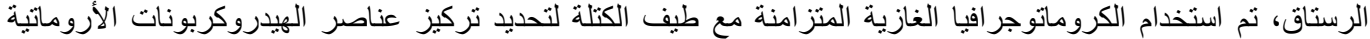

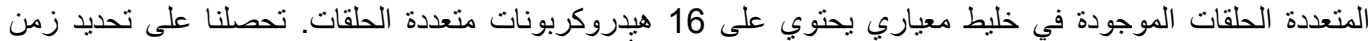

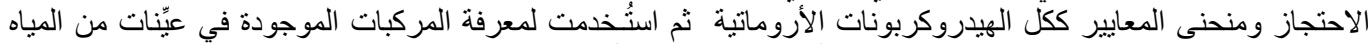

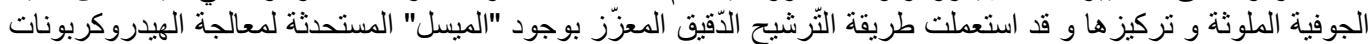

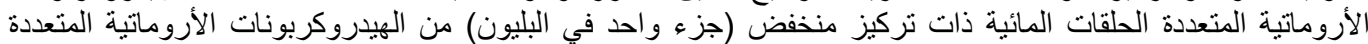

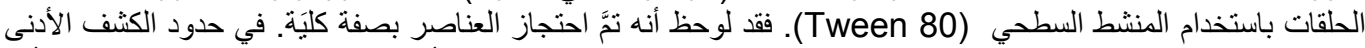
المستعمل (ـ 0.01 جزء في البليون) كان التركيز لعناصر الهيدروكربونات الأروماتية المتعددة الحلقات المتبقية أقل فئل

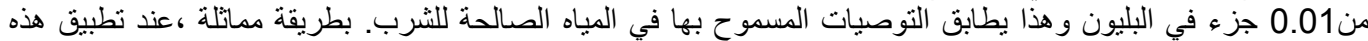

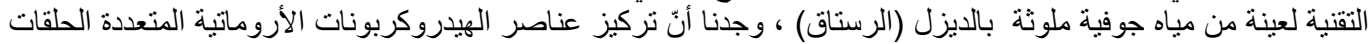

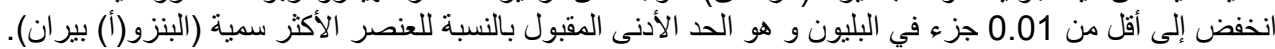

ABSTRACT: In an attempt to analyze polycyclic aromatic hydrocarbons (PAHs) in diesel contaminated underground water in Oman (Rustaq), Gas chromatography-Mass spectrometry was first used to determine the different concentrations in a standard mixture containing 16 PAHs. Retention time and calibration curves were obtained for all aromatic compounds and were used to identify a given analyte as well as its concentration in the contaminated underground water. Micellar enhanced ultrafiltration (MEUF) was then used to treat standard aqueous solution 


\section{MOHAMED AOUDIA et al.}

of PAHs at low concentration ( $\sim 1 \mathrm{ppb})$ using an edible nonionic surfactant (Tween 80$)$. The totality of the mixture components was completely rejected. Within the experimental detection limit $( \pm 0.01 \mathrm{ppb})$, the residual PAH concentrations were less than $0.01 \mathrm{ppb}$ in accord with the allowed concentrations in drinking water. Likewise, excellent rejections of PAHs in MEUF treatment of diesel contaminated underground water at an Omani site (Rustaq) were observed. The concentration of PAHs was reduced to less than $0.01 \mathrm{ppb}$, the accepted limit for the most toxic member of the PAH group (benzo(a)pyrene).

KEYWORDS: Surfactant; Micelle; Enhanced ultrafiltration; Rejection; Retention time.

\section{Introduction}

$\mathrm{C}$ ontamination of aquifers by toxic and/or hazardous organic pollutants such as gasoline and diesel fuels is becoming a critical environmental issue in Oman where about 14 contaminated sites have been identified by the Ministry of Regional Municipalities and Environment. Diesel-range petroleum fractions are extremely complex mixtures containing a large number of organic compounds. Polynuclear aromatic hydrocarbons (PAHs) which may represent about $60 \%$ of volume in diesel are of particular concern as they are either known or suspected carcinogens (Prak and Pritchard, 2002). Their removal presents a challenge to scientists and engineers owing to their low solubility in water and their great tendency to adsorb onto soil and sediments. Therefore, conventional techniques such as pump and treat have proven to be of limited practical value, and significant efforts are being devoted to the development of efficacious approaches for the remediation of PAH contaminated sites. Surfactant flushing was recognized as one of the most promising in situ remediation techniques for contaminated underground water, generating a great deal of interest in surfactant-enhanced aquifer remediation (SEAR) processes (Doung et al. 1996; Volkering et al. 1995; Zhao et al. 2005). Overall, SEAR strategies are commonly characterized by two sequential process stages in situ, namely desorption of the contaminant from the sediment surface and subsequent incorporation of the pollutant into the bulk aqueous phase. Ex-situ treatment can then be achieved by a surfactant-based process known as micellar enhanced ultrafiltration (MEUF). In this process (Baek and Yang, 2004; Aoudia et al. 2003), a surfactant at concentration higher than its critical micelle concentration (CMC) is added to the aqueous stream containing the dissolved hydrocarbons. The micelle causes the organic compounds to solubulize in the micellar core. The stream is then passed through an ultrafiltration membrane having pore sizes small enough to obstruct the passage of micelles, whereby the hydrocarbon molecules will be rejected. As a result, the permeate contains very low concentration of surfactant and organic solutes.

Compared to other conventional separation techniques, MEUF is a relatively low energy, pressure driven, membrane-based separation process. Anisotropic membranes ranging in molecular weight cut-off (MWCO) from 5000 to 50,000 Daltons are generally used to reject micelles from the surfactant stream. However, one major limitation of MEUF is the inevitable leakage of monomer surfactant molecules into the effluent. Since the monomers (surfactant molecules dispersed in the bulk phase in equilibrium with micelles) are not significantly rejected by the membrane, the total surfactant concentration in the permeate is equal or slightly less than the surfactant critical micelle concentration (CMC). Indeed, this was clearly established by Fillipi et al. (1999). One option to tackle this disadvantage is to use biodegradable, non toxic surfactants having extremely low critical micelle concentration. The other option is to use membranes having small MWCO (e.g., 500-1000 Daltons) to recover the monomers for reuse.

The efficiency of MEUF in water treatment is mainly determined by the extent of solubilization enhancement of organic pollutants in the presence of surfactant. Thus, numerous studies have investigated water solubility enhancement of single PAHs in the presence of surfactants above their critical micelle concentrations (Zhu and Feng, 2003; Aoudia and Al-Shaaili, 2006; Hill and Ghoshap, 2002; Aoudia et al. 2010). This solubility enhancement has been convincingly related to the surfactant and solute structure and to the PAH-micelle interaction (Prak and Pritchard, 2002). However, only a limited number of investigations have been reported 


\section{MICELLAR ENHANCED ULTRAFILTRATION}

where effects of multiple solutes on micellar solubilization of an individual component were examined. Thus, solubilization of binary mixtures of hydrocarbon (benzene and hexane) in anionic and nonionic surfactants systems was investigated by Chaiko et al. (1984). The authors reported selective solubilization in some mixtures and a synergistic effect on the solubilization of hexane in the presence of small amounts of benzene. These studies showed evidence that the less hydrophobic solute (benzene) partitioned at the micellar core-water interface caused the interfacial tension to decrease, which consequently enabled the micellar core volume to increase, resulting in a greater solubility of the more hydrophobic compound (hexane). Solubilization of pyrene, fluoranthrene, and phenantrene from binary and ternary mixtures in nonionic surfactant solutions were investigated by Prak and Pritchard (2002). The extent of solubilization was shown to be greatly influenced by the PAH structure, PAH-PAH interactions, PAH-micelle interaction, and PAH packing within the micelle.

Using such simple binary and ternary PAH mixtures, it was clearly demonstrated that the singlecomponent micellar partition coefficient cannot be used to predict the multicomponent micellar solubilization. In the presence of a co-solute, the concentration of organic compounds in micellar solutions may decrease, remain the same, or increase over single component systems depending on the co-solute and the surfactant structures (Guha et al. 1998; Jacobson and Casassa, 1991; Underwood et al. 1993). Likewise, most MEUF studies focused on the removal of single PAH solutes from an aqueous stream (Dunn et al. 1985; Dunn et al. 1987; Khandori and Schechter, 1990; Edwards et al. 1991; Hong and Yang, 1994; Kim et al. 1998; Jachowska et al. 2002; Syamal and Bhattacharya, 1997). Very few addressed the rejection of PAHs in mixtures (Talens-Alesson et al. 2001; Bielska and Szymanowski, 2004; Jadhav et al. 2001) and evidence was found that removal of individual PAHs and other organic compounds when solubilized in mixtures is not related in a simple manner to their single solute rejection from aqueous systems. For instance, the removal of phenol, p-cresol, xylenol in simultaneous micellar-enhanced ultrafiltration process showed that the highest rejection was observed with the most hydrophobic xylenol (Witek et al. 2006). MEUF of different phenolic derivatives including metanitrophenol (MNP), catechol (CC), paranitrophenol (PNP), and beta-napthol (BN) in their binary mixture has been studied by Purkait et al. (2005). Retention of solutes was found to be less in the case of the two-component feed solution compared to the single-component feed solution, suggesting that even for simple multiple systems (binary and ternary), the rejection of each cannot be predicted by its rejection from single-component system. Clearly, binary and ternary PAH mixtures are not realistic models for their solubilization in diesel contaminated sites where PAHs mostly exist in mixtures containing a large number of organic compounds. Therefore, the main objective of this work is to investigate the efficiency of MEUF in removing PAH pollutants from a standard aqueous PAH mixture containing sixteen components using an edible surfactant (Tween 80). This mixture can be considered to be a realistic model mixture of $\mathrm{PAH}$ in the diesel-range petroleum fraction, a source of environmental concern in Oman due to leakage of underground gasoline station storage tanks in many sites in the Sultanate. The concentration of each PAH component will be purposely limited to about $1 \mathrm{ppb}$ in order to assess the efficiency of the MEUF process in removing such extremely low amounts of organic solutes due to the fact that the recommended total PAHs concentration in drinking water supply is $\sim 0.20 \mathrm{ppb}$ whereas that of their most toxic member benzo(a)pyrene is $0.010 \mathrm{ppb}$ (Omani Standards for Unbotteled Drinking Water No. 245/1993). Furthermore, the removal of PAHs from diesel contaminated underground water in Oman (Rustaq) via micellar enhanced ultrafiltration will also be evaluated

\section{Experiment}

\subsection{Materials}

Surfactant Tween 80 (Molecular weight of $1310 \mathrm{~g} / \mathrm{mol}, \mathrm{CMC}=0.0013 \mathrm{~g} / \mathrm{dliter}$ ) was purchased from Sigma (USA) and used without further modification. Standard mixtures of polycyclic aromatic hydrocarbons were purchased from ULTRA Scientific (USA). The concentration of each mixture was $2000 \mu \mathrm{g} / \mathrm{ml}$ in methanol for each single compound. Dichloromethane $\left(\mathrm{CH}_{2} \mathrm{Cl}_{2}, 99.5 \%\right.$ pure) was supplied by S.d fine-chem Ltd (USA). Sodium hydroxide pellets $(98.0 \%)$ and sodium hypochlorite solution (12\% chlorine) were obtained from Qualigens and BDH, respectively. Sodium sulphate anhydrous, $99 \%$ (purchased from Qualigens) was used as 


\section{MOHAMED AOUDIA et al.}

received. Ultrapure water $18.2 \mathrm{M} \Omega$ (milliQ Millipore corporation) was used to prepare standard solutions. The ultrafiltration membrane, supplied by Millipore, was regenerated cellulose with MWCO 10,000 Daltons (Type YM). The effective membrane area was $31.65 \mathrm{~cm}^{2}$.

\subsection{Methods}

\section{Ultrafiltration}

Ultrafiltration experiments were performed at room temperature using an Amicon 8200 batch stirred cell. The feed volume of the solution was $180 \mathrm{ml}$ and the pressure in the batch cell was maintained at $80-100 \mathrm{kPa}$ by nitrogen gas. The ultrafiltration process began by placing the membrane with the glossy side facing upwards on the support at the bottom of the cell. The cell was then fixed tightly, filled with distilled water and pressurized with nitrogen gas. The water flux was measured to determine the permeability of the freshly used membrane. The feed solution was prepared by dissolving the required amount of surfactant in deionized water. The feed solution in the cell was stirred with a triangular stirrer at a constant stirring speed. The run was continued until $150 \mathrm{ml}$ of the permeate ( $80 \%$ of the feed volume) had been collected, and the flux was monitored at different times during the entire ultrafiltration experimental run. After each run, the entire cell, stirrer and membrane were washed with distilled water to remove any deposition. The used membrane was rinsed with $0.1 \mathrm{M} \mathrm{NaOH}, 100$ ppm $\mathrm{NaOCl}$ for 30 minutes and then flushed with distilled water and stored in $10 \%$ ethanol /water (v/v) solution in the refrigerator. The water permeability of the membrane was measured before each run and was found to be similar to that measured for the freshly used membrane.

\section{Preparation of Standard Solutions}

Polynuclear aromatic hydrocarbons (PA) standard mixture (1.0 ppb) was prepared from the stock standard mixture (2000 ppm) by two successive dilutions. First, $5.0 \mu \mathrm{L}$ of the stock mixture was diluted to $750.0 \mathrm{~mL}$ with de-ionized water (this is called the working solution). Then, $75.0 \mu \mathrm{L}$ of working solution was diluted to 1000.0 $\mathrm{mL}$ with de-ionized water to obtain the desired final concentration.

The concentration of each PAH component was then determined accurately from their corresponding calibration curves.

\section{Liquid-Liquid Extraction}

PAHs were extracted from aqueous solution by solvent extraction with dichloromethane. Two $500 \mathrm{ml}$ volumetric flasks were filled to the mark, one with the contaminated water and the other with the treated water (permeate). Each entire sample was poured into a $500 \mathrm{ml}$ separatory funnel and then extracted 5 times in dichloromethane with $10 \mathrm{ml}$ increments each time. Sodium sulfate anhydrous was added to the extractant to ensure the complete removal of water molecules. The drying agent was then removed by filtration in preweighed $100 \mathrm{ml}$ round bottomed flasks. After extraction, the two samples were concentrated in a rotary evaporator but not to dryness, then weighed again to the nearest $0.1 \mathrm{mg}$. The volume left was calculated and adjusted to a final volume of $1 \mathrm{ml}$.

\section{Analysis}

The analysis of the different samples was carried out with a Varian CP 3800 gas chromatograph coupled with Saturn $2000 \mathrm{MS} / \mathrm{MS}$, a ComboiPal headspace, and SPME autosampler. The column used was a CP Sil 8 CB type column $(30 \mathrm{~m} \times 0.25 \mathrm{~mm} \times 0.25 \mathrm{df})$. Ultrapure helium was used as a carrier gas. The frit sample traps $5 \mathrm{ml}$ of the sample and then purged it for $12 \mathrm{~min}$.

The GC-MS instrument was calibrated with the PAH standard mixtures at different concentrations. The column temperature was set at $70{ }^{\circ} \mathrm{C}$ for $1.50 \mathrm{~min}$, then programmed to $200{ }^{\circ} \mathrm{C}$ at $10.0^{\circ} \mathrm{C} / \mathrm{min}$, followed by increase to $270{ }^{\circ} \mathrm{C}$ at a rate of $5.0^{\circ} \mathrm{C} / \mathrm{min}$ and finally to $300{ }^{\circ} \mathrm{C}$ at $10.0{ }^{\circ} \mathrm{C} / \mathrm{min}$. The column was then held for $10.0 \mathrm{~min}$ with a total run time of $41.50 \mathrm{~min}$. The sample analysis began with injecting of $2 \mu \mathrm{L}$ of the extract to 


\section{MICELLAR ENHANCED ULTRAFILTRATION}

the splitless injection port of the instrument and then processing the sample with the output referred to the appropriate calibration curve.

\section{Results and Discussion}

\subsection{Micellar enhanced ultrafiltration of a standard aqueous PAH Mixture}

GC-MS analysis was carried out for a prepared standard PAH mixture containing 16 compounds. The retention time for each component was measured and reported in Table 1. Standard injections were performed with four different concentrations $(1,2,5$, and $10 \mathrm{ppb})$ for each $\mathrm{PAH}$ component in the mixture to obtain different calibration curves. A typical calibration curve is shown in Figure 1 for anthracene.

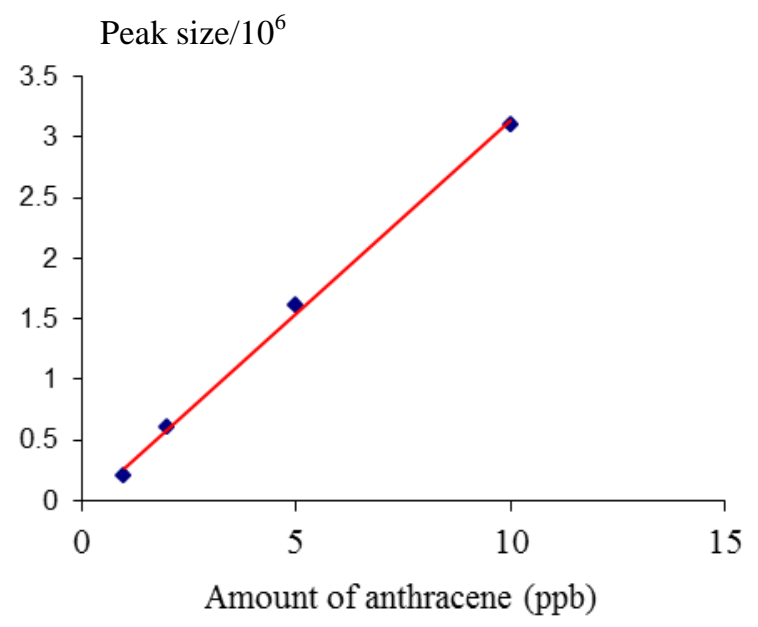

Figure 1. Calibration curve for anthracene in the standard PAH mixture.

The micellar enhanced ultrafiltration process was then applied to treat a synthetic aqueous solution containing the standard PAH mixture using an edible nonionic surfactant (Tween 80).

Table 1. Retention times $R_{\mathrm{t}}$ (in minutes) for the different components in the standard PAH mixture.

\begin{tabular}{|c|c|c|c|c|c|}
\hline No. & Compound name & $\boldsymbol{R}_{\mathbf{t}}$ & No. & Compound name & $\boldsymbol{R}_{\mathbf{t}}$ \\
\hline 1 & Naphthalene & 7.693 & 9 & Benz(a)anthracene & 24.648 \\
\hline 2 & Acenaphthylene & 11.389 & 10 & Chrysene & 24.793 \\
\hline 3 & Acenaphthene & 11.812 & 11 & Benzo(j)fluoranthene & 29.025 \\
\hline 4 & Fluorene & 13.052 & 12 & Benzo(k)fluoranthene & 29.025 \\
\hline 5 & Phenenthrene & 15.399 & 13 & Benzo(a)pyrene & 30.099 \\
\hline 6 & Anthracene & 15.535 & 14 & Indeno(1,2,3-cd)pyrene & 33.370 \\
\hline 7 & Fluoranthene & 19.063 & 15 & Dibenz(a,h)anthracene & 33.497 \\
\hline 8 & Pyrene & 19.841 & 16 & Benzo(ghi)perylene & 34.218 \\
\hline
\end{tabular}




\section{MOHAMED AOUDIA et al.}

Obviously, there is a legitimate concern over adding surfactant to the contaminated water at surfactant concentration above its CMC and possibly trading one contaminant (PAH) with another (surfactant). To allay this concern, the use of a food additive surfactant may be a relatively safe approach (Schick, 1967).

GC-MS analysis was carried out to estimate the concentration of each PAH solute in permeate, using the appropriate calibration curve. The total ion chromatogram obtained is shown in Figure 2 (green), along the total ion chromatogram for a similar non-treated synthetic aqueous standard PAHs mixture (red). Interestingly, all chromatogram peaks were significantly removed by MEUF treatment. This finding strongly suggests that MEUF by Tween 80 surfactant micelles may be very efficient in removing PAH solutes from the aqueous stream. Figure 2 was used along the PAH calibration curves (determined for standard PAH mixture) to estimate the rejection percent $(R \%)$ of each $\mathrm{PAH}$ component in the mixture from the following expression where $C_{0}$ is the initial concentration of the PAH solute in the feed standard mixture and $C_{\mathrm{p}}$ is the permeate solute concentration.

$$
R \%=\left[1-\left(C_{\mathrm{p}} / C_{0}\right)\right]
$$

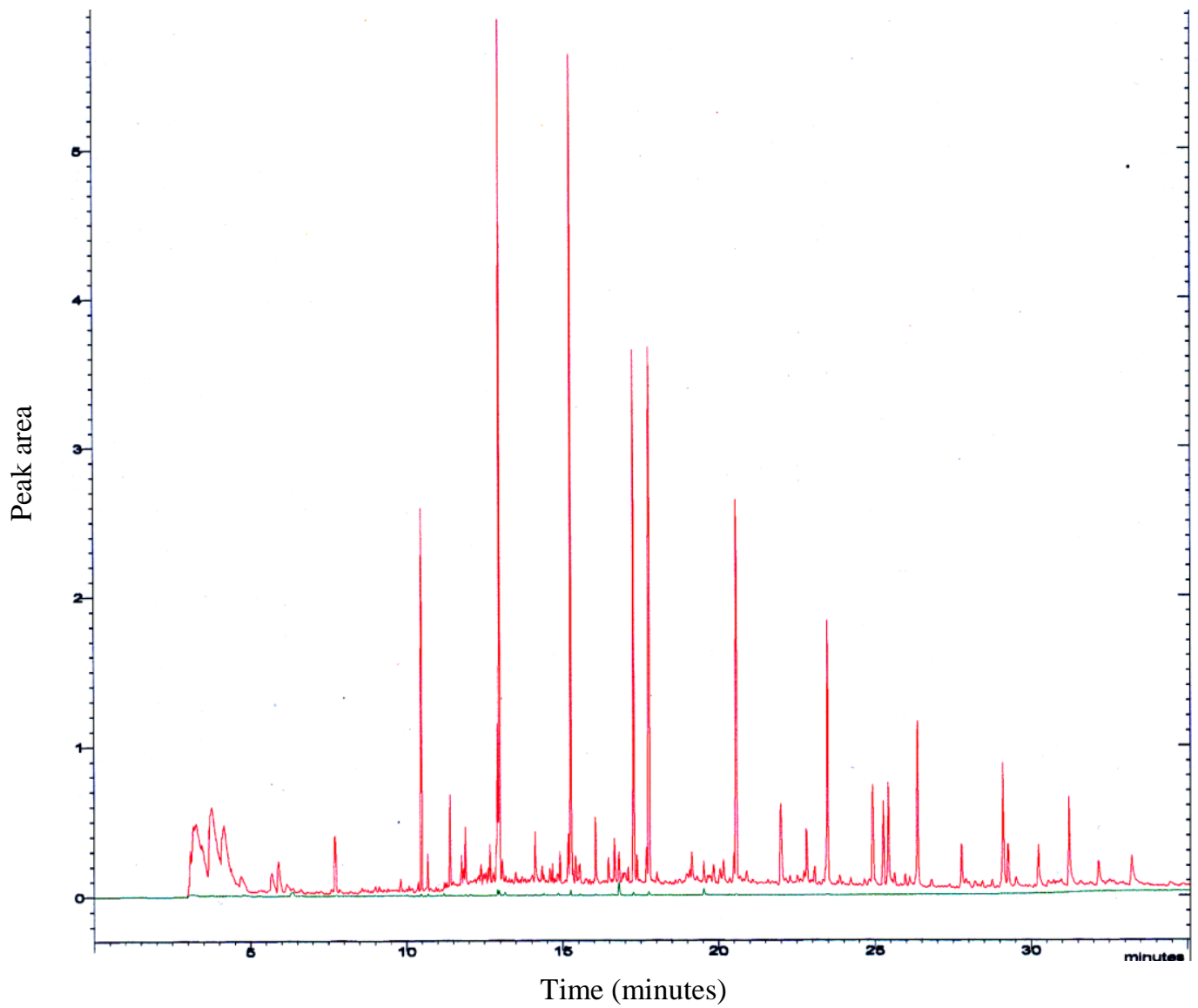

Figure 2. Overlaid total ion chromatogram of a non-treated standard PAH mixture (red) and a MEUF treated standard PAH mixture (green) using Tween $80(10 \times \mathrm{CMC})$.

The detection limit of our GC-MS system used in this study is $\pm 0.010 \mathrm{ppb}$. Thus, we decided to calculate a lower limit for the rejection percent by using a residual solute concentration equal to $0.010 \mathrm{ppb}$ for those PAHs that are completely removed. Such lower limits are reported in Table 2. 


\section{MICELLAR ENHANCED ULTRAFILTRATION}

Table 2. Removal of PAHs from a standard mixture of PAHs by MEUF using Tween $80(10 \times$ CMC).

\begin{tabular}{|l|l|c|c|c|}
\hline No. & \multicolumn{1}{|c|}{ Compound name } & $\mathbf{C}_{\mathbf{o}}(\mathbf{p p b})$ & $\begin{array}{c}\mathbf{C}_{\mathbf{p}} \\
\mathbf{( 0 . 0 1 0} \mathbf{~ p p b})\end{array}$ & $\mathbf{R \%}$ \\
\hline 1 & & & $\mathrm{Ud}^{*}$ & 98.7 \\
\hline 2 & Naphthalene & 0.799 & $\mathrm{Ud}$ & 98.8 \\
\hline 3 & Acenaphthyle & 0.810 & $\mathrm{Ud}$ & 98.7 \\
\hline 4 & Fluorene & 0.747 & $\mathrm{Ud}$ & 98.9 \\
\hline 5 & Phenenthrene & 1.033 & $\mathrm{Ud}$ & 99.0 \\
\hline 6 & Anthracene & 1.018 & $\mathrm{Ud}$ & 99.0 \\
\hline 7 & Fluoranthene & 0.902 & $\mathrm{Ud}$ & 98.9 \\
\hline 8 & Pyrene & 0.890 & $\mathrm{Ud}$ & 98.9 \\
\hline 9 & Benz(a)anthracene & 0.873 & $\mathrm{Ud}$ & 98.9 \\
\hline 10 & Chrysene & 0.872 & $\mathrm{Ud}$ & 98.9 \\
\hline 11 & Benzo(j)fluoranthene & 0.784 & $\mathrm{Ud}$ & 98.7 \\
\hline 12 & Benzo(k)fluoranthene & 0.844 & $\mathrm{Ud}$ & 98.8 \\
\hline 13 & Benzo(a)pyrene & 0.740 & $\mathrm{Ud}$ & 98.8 \\
\hline 14 & Indeno(1,2,3-cd)pyrene & 0.915 & $\mathrm{Ud}$ & 98.7 \\
\hline 15 & Benzo(ghi)perylene & 0.960 & $\mathrm{Ud}$ & 98.9 \\
\hline 16 & Dibenz(a,h)anthracene & & $\mathrm{Ud}$ & 98.9 \\
\hline
\end{tabular}

*Ud: Undetected

As clearly seen in this Table, high PAHs rejections (> 98.7\%) were obtained for all components, reflecting a significant efficiency of MEUF in removing PAHs from water. Interestingly, because of the relatively low PAH concentrations used in our experiments (0.800-1.000 ppb), these high PAH rejections show that MEUF is very effective at low solute concentration, an evident advantage over conventional separation techniques such as liquid-liquid extraction, adsorption onto activated carbon or distillation. It is worth noting that aromatic hydrocarbons have a great tendency to adsorb at surfaces and as a result, part of the rejection of aromatics may also be attributed to the solute-membrane interaction in addition to their solubility enhancements in the presence of Tween 80 micelles.

It is well recognized that PAHs are very hydrophobic and have a very low solubility in water. For instance, their solubility ranges from $32.5 \mathrm{ppm}$ for naphthalene to $0.14 \mathrm{ppm}$ for pyrene. The recommended total PAH concentration in drinking water supply is $0.20 \mathrm{ppb}$ whereas that of their most toxic member benzo(a)pyrene is $0.010 \mathrm{ppb}$ (Omani Standards for Unbottled Drinking Water No. 245/1993). It is, therefore, very essential to reduce the concentration of these hazardous chemicals present in contaminated water to $0.20 \mathrm{ppb}$ total concentration as well as to less than $0.010 \mathrm{ppb}$ for the most toxic ones. Indeed, in the range of PAH concentration investigated in this study $(0.800-1.000 \mathrm{ppb})$, the residual concentration of each solute present in the standard PAHs mixture was reduced to $\leq 0.010 \mathrm{ppb}$, in accord with the Oman standards for unbottled drinking water. In fact, several water treatment methods can be used in order to go from high contaminant concentrations to low, but few effective methods can go from minute concentrations to nil or extremely low concentration. MEUF is one of these methods in which efficiency increases as the contaminant concentration decreases.

At this juncture, it is worth noting that in diesel contaminated underground water (a real concern for the Sultanate of Oman), PAHs are generally found in mixtures with a considerable number of organic compounds with different: $i$ ) structure, $i$ ) hydophobicity, iii) solubility locus in micelle, and $i v$ ) micelle-solute interaction. One may, therefore, assume that hydrocarbons with similar hydrophobicity and/or hydrophilicity could compete for a similar site of solubilization in the micelle. This mutual competitive solubilization within the micelle will certainly influence the solubilization behavior of the PAHs (and therefore their rejection by MEUF) in real diesel 


\section{MOHAMED AOUDIA et al.}

contaminated underground water relatively to their solubilization in PAH standard mixtures. To elucidate this important issue, we investigated the rejection of PAHs from diesed contaminated water in Oman (Rustaq) by MEUF using Tween 80 surfactant.

\subsection{Micellar enhanced ultrafiltration of PAHs from diesel contaminated underground water (Rustaq)}

MEUF was applied to treat diesel contaminated underground water (Rustaq, Oman) using Tween 80. Total ion chromatograms are shown in Figure 3. The red chromatogram corresponds to the non treated contaminated water sample, whereas the green chromatogram corresponds to the contaminated underground water sample treated by MEUF. All the identified PAH components in the non-treated contaminated water are shown in Table 3 and their concentrations were estimated from their calibration curves. Total ion chromatogram (Figures 3) was used along the calibration curve for each identified PAH to calculate the displayed percent rejection $R \%$ in Table 3. Figure 3 shows that, within the experimental error, our results indicate a complete removal of the identified PAH components from the diesel contaminated water sample, indicating that MEUF is also a very effective separation technique in the seldom-investigated extremely low pollutant concentration condition (less than 1 $\mathrm{ppb})$.

Table 3. Removal of identified PAH diesel components from contaminated underground water (Rustaq) by MEUF using Tween $80(10 \times$ CMC).

\begin{tabular}{|l|l|c|c|c|}
\hline No & \multicolumn{1}{|c|}{ Compound name } & $\boldsymbol{C}_{\mathbf{o}}(\mathbf{p p b})$ & $\begin{array}{c}\boldsymbol{C}_{\mathbf{p}} \\
\mathbf{\mathbf { 0 . 0 1 0 }} \mathbf{p p b}\end{array}$ & $\boldsymbol{R} \%$ \\
\hline 1 & Naphthalene & 0.413 & $\mathrm{Ud}^{*}$ & 97.6 \\
\hline 2 & 2-Methylnaphthalene & 0.419 & $\mathrm{Ud}$ & 97.6 \\
\hline 3 & 2,6 -dinitrotoluene & 0.655 & $\mathrm{Ud}$ & 97.5 \\
\hline 4 & Dibenzofuran & 0.353 & $\mathrm{Ud}$ & 97.2 \\
\hline 5 & Azobenzene & 0.452 & $\mathrm{Ud}$ & 92.3 \\
\hline 6 & Phenanthrene & 0.537 & $\mathrm{Ud}$ & 98.1 \\
\hline 7 & Anthracene & 0.533 & $\mathrm{Ud}$ & 98.1 \\
\hline 8 & Carbazole & 0.792 & $\mathrm{Ud}$ & 98.7 \\
\hline 9 & Flouranthene & 0.482 & $\mathrm{Ud}$ & 97.9 \\
\hline 10 & Pyrene & 0.527 & $\mathrm{Ud}$ & 98.1 \\
\hline 11 & Benz(a) anthracene & 0.741 & $\mathrm{Ud}$ & 98.7 \\
\hline 12 & Chrysene & 0.733 & $\mathrm{Ud}$ & 98.6 \\
\hline 13 & Benzo(b)flouranthene & 0.801 & $\mathrm{Ud}$ & 98.8 \\
\hline 14 & Benzo(k) fluoranthene & 0.801 & $\mathrm{Ud}$ & 98.8 \\
\hline 15 & Benzo(a) pyrene & 1.031 & $\mathrm{Ud}$ & 98.8 \\
\hline 16 & Benzo(ghi) perylene & $\mathrm{Ud}$ & 99.0 \\
\hline
\end{tabular}

*Ud: Undetected

In treating contaminated water for drinking purpose by MEUF, the main criteria (among others) imposed on the choice of surfactant is related to safety and toxicity considerations. As previously discussed, MEUF treated water will inevitably contain surfactant at a concentration equal or slightly less than the surfactant CMC (Fillipi et al. 1999). The CMC of Tween 80 is $1.2 \times 10^{-5} \mathrm{M}$ (Aoudia and Al-Shuaily, 2006). This corresponds to a permeate surfactant concentration equal to $15.72 \mathrm{mg} / \mathrm{L}$. Toxicity and carcinogenecity studies of Tween 80 indicated a recommended concentration acceptable for safe human daily consumption not exceeding $25 \mathrm{mg} / \mathrm{kg}$ of body weight. An average person can therefore ingest up to $1750 \mathrm{mg}$ of Tween 80 daily without any potential danger, thereby the concentration of Tween 80 in the treated water is extremely low and safe. 


\section{MICELLAR ENHANCED ULTRAFILTRATION}

\section{Conclusion}

Micellar enhanced ultrafiltration (MEUF) was applied to the treatment of a standard polycyclic aromatic hydrocarbon (PAH) mixture containing 16 components and a diesel contaminated underground water in Rustaq (Sultanate of Oman), using an edible nonionic surfactant (Tween 80). Gas-chromatography-mass spectrometry (GC-MS) was carried out to analyze solutes in the treated and untreated aqueous stream.

Within the experimental error $( \pm 0.01 \mathrm{ppb})$, the totality of PAH compounds in the standard mixture were substantially removed ( $\% R>98.1 \%$ ), even though their initial concentrations in standard mixture were extremely low $(<1 \mathrm{ppb})$. This interesting result suggests that toxic solutes can be effectively removed by MEUF at extremely low concentration.

Likewise, the concentration of the totality of PAH identified in the diesel contaminated underground water was reduced to less than $\pm 0.01 \mathrm{ppb}$ by MEUF using Tween 80 surfactant, which is below the recommended PAH concentration in drinking water supply for the most toxic member of the PAH group (benzo(a)pyrene, $0.010 \mathrm{ppb})$.

The permeate surfactant concentration is $15.72 \mathrm{mg} / \mathrm{L}$ which corresponds to much less than the recommended maximum safe human daily consumption of $1750 \mathrm{mg}$ of Tween 80.

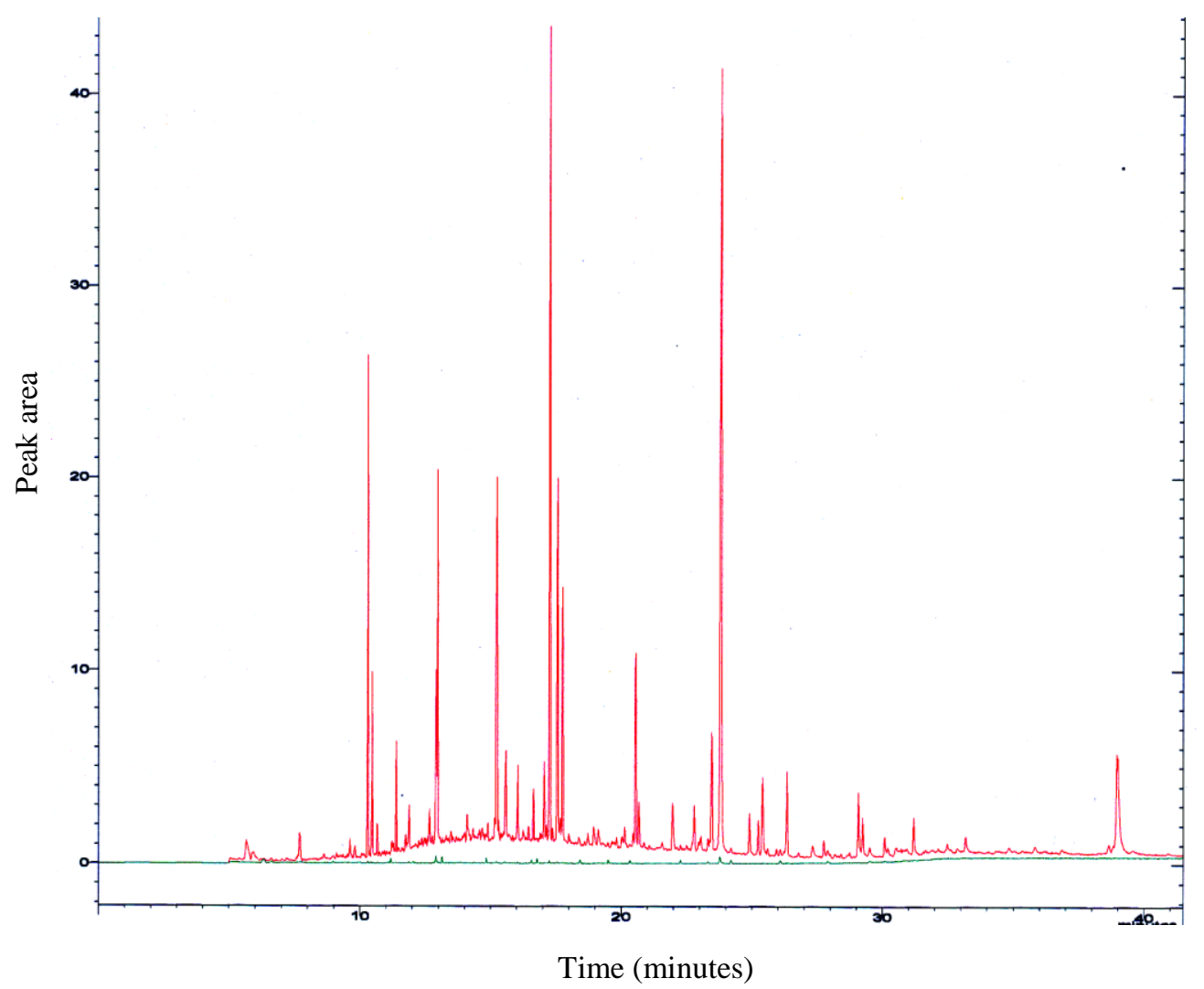

Figure 3. Overlaid total ion chromatogram of a non treated contaminated underground water sample from Rustaq (red) and a similar underground water sample treated by MEUF (green) using Tween $80(10 \times$ CMC). 


\section{MOHAMED AOUDIA et al.}

\section{Acknowledgment}

We thank Sultan Qaboos University, Sultanate of Oman for the financial support (Grant: IG/ SCI / CHEM / 03 /03).

\section{References}

AOUDIA, M., ALLAL, N., DJENNET, H., TOUMI, L., 2003. Dynamic Micellar Enhanced Ultrafiltration: Use of Anionic (SDS)-nonionic (NPE) System to Remove $\mathrm{Cr}^{3+}$ at Low Surfactant Concentration, J. Membr. Sci, 217: 181-192.

AOUDIA, M., Al-SHAAILI. M., 2006. Solubilization of Naphthalene and Pyrene by Sodium Dodecyl Sulfate (SDS) and Polyoxyethylenesorbitan Monooleate (Tween 80) Mixed Micelles, Colloids and Surfaces A: Physicochem. Eng. Aspects, 287: 44-50.

AOUDIA, M., AL-HADDABI, B., AL-HARTHI, Z., AL-RUBKHI, A., 2010. Sodium Lauryl Ether Sulfate Micellization and Water Solubility Towards Naphthalene and Pyrene: Effect of the Degree of Ethoxylation, J. Surfact Detergtg, 13: 103-111.

BAEK, K., YANG, J.W., 2004. Simultaneous Removal of Chlorinated Aromatic Hydrocarbons, Nitrate and Chromate Using Miceller-Enhanced Ultrafiltration, Chemosphere, 57: 1091-1097.

BIELSKA, M., SZYMANOWSKI, J., 2004. Micellar Enhanced Ultrafiltration of Nitrobenzene and 4Nitrophenol, J. Membr. Sci, 243: 273-281.

CHAIKO, M.A., NAGARAKJAN, R., RUCKENSTEIN, E., 1984. Solubilization of Single Components and Binary Mixtures of Hydrocarbons in Aqueous Micellar Solutions, J. Colloid Interface Sci, 99: 168-182.

DOUNG, R.A., LEI, W.G., CHEN, T.F., LEE, C.Y., CHEN, J.H., CHANG, W.H., 1996. Effects of Anionic Surfactants on Sorption and Micellar Solubilization of Monoaromatic Compounds. Wat. Sci. Tech, 34: $327-$ 334.

DUNN, R.O., SCAMEHORN, J.F., CHRISTIAN, S.D., 1985. Use of Micellar Enhanced Ultrafiltration to Remove Dissolved Organics from Aqueous Streams, Separ. Sci. Technol. 20: 257.

DUNN, R.O., SCAMEHORN, J.F., CHRISTIAN, S.D., 1987. Concentration Polarization Effects in the Use of Micellar Enhanced Ultrafiltration to Remove Dissolved Organic Pollutants From Waste Water, Separ. Sci. Technol. 22: 763.

EDWARDS, D.A., LUTHY, R.G., LIU, Z., 1991. Solubilization of Polycyclic Aromatic Hydrocarbons in Micellar Nonionic Surfactant Solutions, Environ. Sci. Technol, 25: 127.

FILLIPI, B.R., BRANT, L.W., SCAMEHORN, J.F., CHRISTIAN, S.D., 1999. Use of Micellar-Enhanced Ultrafiltration at Low Surfactant Concentrations and with Anionic-Nomionic Surfactant Mixtures, J. Colloid Interface Sci, 213: 68-80.

GUHA, S., JAFFE, P.R., PETERS, C.A., 1998. Solubilization of PAH Mixtures by a Nonionic Surfactant, Environ. Sci. Technol, 32: 930-945.

HILL, A., GHOSHAP, S. 2002. Micellar Solubilization of Naphyhalene and Phenanthrene fron NonaqueousPhase Liquids, Environ. Sci. Tehnol. 36: 3901-3907.

HONG, J.J., YANG, S.M., 1994. Continuous Separation of Phenol from Aqueous Stream Using Micellar Enhanced Ultrafiltration (MEUF), J. Chem. Eng. Japan, 2 (3): 314.

JACOBSON, A.M., CASSASSA, E.Z., 1991. Multicomponent Solubilization in Aqueous Micelles of Dodecyland Tetradecyltriammonium Bromide: Solubilization equilibria, J Colloid Interface Sci, 142: 480-488.

JADHAV, S.R., VERMA, N., SHARMA, A., BHATTACHARAYA, P.K., 2001. Flux and Retention Analysis During Micellar Ultrafiltration for the Removal of Phenol and Aniline, Separation and Purification Technology, 24: 541-557.

JACHOWSKA, M., ADAMEZAK, H., SZYMANOWSKI, J., 2002. Ultrafiltration Characteristics of Oxyethylated Methyl Dodecanoate Aqueous Solutions, Colloids Surf, 186: 11. 


\section{MICELLAR ENHANCED ULTRAFILTRATION}

KIM, C.K., KIM, S.S., LIM, J.C., 1998. Removal of Aromatic Compounds in Aqueous Solutions via Micellar Enhanced Ultrafiltration: Part 1. Behavior of Nonionic Surfactants, J. Membrane. Sci, 147: 13.

KHANDORI, K., SCHECHTER, R.S., 1990. Selection of Surfactants for Micellar-enhanced Ultrafiltration, Separ. Sci. Technol, 25 (1\&2): 83.

NAGARAKJAN, R., CHAIKO, M.A., RUCKENSTEIN, E., 1984. Locus of Solubilization of Benzene in Surfactant Micelles, Journal of Physical Chemistry, 88: 2916-2922.

PRAK, D.J.L., PRITCHARD, P/H., 2002. Solubilization of Polycyclic Aromatic Hydrocarbons Mixtures in Micellar Nonionic Surfactant Solutions. Water Research, 36: 3463-3472.

PURKAIT, M.K., DASKUPTA, S., DE, S., 2005. Micellar Enhanced Ultrafiltration of Phenolic Derivatives from their Mixtures, J Colloid Interface Sci, 285: 395-402.

SHICK, M (Editor), Nonionic Surfactants, Dekker, New York (1967), p. 644.

SYAMAL, M.D., BHATTACHARYA, P.K. 1997. Phenol Solubilization by Cetyl Pyridinium Chloride Micelles in Micellar Enhanced Ultrafiltration, J. Membr. Sci, 137: 99.

TALENS-ALESSON, F.I., URBANSKI, R., SZYMANOWSKI, J., 2001. Evolution of Resistance to Permeation During Micellar Enhanced Ultrafiltration of Phenol and Aniline, Colloids and Surfaces A: Physicochemical and Engineering Aspects, 178: 71-77.

UNDERWOOD, J.L., DEBELAK, K.A., WILSON, D.J., MEREAS, J.M., 1986. Soil Clean up by In-situ Surfactant Flushing. V. Micellar Solubilization of some Aromatic Compounds. Separ. Sci. Technol, 28: 1527-1537.

VOLKERING, F., BREURE, A.M., ANDREI, J.G.A., RULKENS, W.H., 1995. Influence of Nonionic Surfactants on Bioavailability and Biodegradation of Polycyclic Aromatic Hydrocarbons. Appl. Environ. Microbiol, 6: 1699-1705.

WITEK, A., KO, A., KURCZEWSKI, B., RADZEJOWSKA, M., and HATALSKI, M., 2006. Simultaneous Removal of Phenols and Cr3+ using Micellar-enhanced Ultrafiltration Process, Desalination, 191: 111116.

ZHAO, B., ZHU, L., Li, W., CHEN, B., 2005. Solubilization and Biodegradation of Phenanthrene in Mixed Anionic-nonionic Surfactant Solutions, Chemosphere, 58: 33-40.

ZHU, L., FENG, S., 2003. Synergistic Solubilization of Polycyclic Aromatic Hyderocarbons by Mixed AnionicNonionic Surfactants, Chemosphere, 53: 459-467.

Received: 12 December 2010

Accepted: 4 June 2011 